\title{
血液細胞および神経系組織における糖脂質の多様な役割
}

\author{
武 富 保 \\ 信州大学医学部附属心脈管病研究施設生化学部門 函 390 長野県松本市旭 3-1-1
}

\section{Heterogenous biological roles of glycosphingolipids both in various kinds of blood cells and in the nervous tissues}

\section{Tamotsu Taketomi}

\begin{abstract}
Department of Lipid Biochemistry, Institute of Cardiovascular Diseases, Shinshu University School of Medicine, Matsumoto, Nagano 390, Japan
\end{abstract}

General review on the recent progress of glycosphingolipids was described both in various kinds of blood cells and in the nervous tissues. First, the cell membrane glycosphingolipids were summarized and discussed as important markers for the maturation and differentiation from immature blood cells to mature myeloid and lymphoid cells, erythrocytes and platelets, as specific ligands to some selectins for cell-cell recognition and as roles of immunological responses.

Second, the biological significance of myelin lipids, particularly cerebroside and sulfatide, changes of neuronal gangliosides in the development of neuronal cells, abnormal gangliosides in the brain tumors and biological activities of gangliosides were mentioned.

Key word : Membrane glycosphingolipids of leukocytes, erythrocytes and platelets, cell maturation and differentiation, myelin lipids, neuronal gangliosides

\section{1.はじめに}

筆者はこれまで糖脂質の研究に長年従事して来たが, この分野の歴史を振り返って見て, 初めは谷間の渓流に 思われた分野が, やがては, 生化学全般の進歩・発展に 伴い, また, 科学技術の開発がもたらした大型分析機器 の導入によって, 小中規模の河川へと広がり,ついには, 遠々と流れる大河へとなって来ている姿を今日, 見るこ とができるのは大変慶賀すべきことのように思ってい る.

大河になれば，それだけ護岸工事も浚渫作業も大事な ことであり，また，河川の利用法も色々と国土保全や自 然環境保護とともに考察されなければならない.

それだけに，この分野はこれからもますます色々と新
しい角度から大小様々の規模で研究されるに值するもの であることを確信している.

この分野の草創から発展に至る貴重な歴史の資料とし て，山川民夫著「糖脂質物語」を紹介したい"1).

糖脂質は言うまでもなく, 脊椎動物ではほとんどがス フィンゴ糖脂質 (Glycosphingolipids, GSLs) で, ス フィンゴシン塩基のアミノ基に脂肪酸が酸アミド結合し た疏水性のセラミドに親水性のオリゴ糖がグリコシド結 合したものである。この糖脂質のセラミド部分が細胞膜 脂質二重層の中に埋めこまれ, オリゴ糖部分を細胞外表 層に向け存在する.このオリゴ糖鎖の構造だけでも 250 種 以上あり,この 10 年間だけでも, その半分以上が新た に発見されたものである. 糖脂質は動物種や細胞や組織 に特異的なパターンを示し, 細胞の識別マーカーの役割 
表 1. 本稿に掲載された糖脂質の構造

\begin{tabular}{|c|c|}
\hline 糖脂質 & 造 \\
\hline GlcCer & Glc $\beta$ 1-1 Cer \\
\hline LacCer & Gal $\beta$ 1-4 GlcCer \\
\hline Gb3 & Gal $\alpha 1-4$ Gal $\beta 1-4$ GlcCer \\
\hline Gb4 & GalNAc $\beta 1-3$ Gal $\alpha 1-4$ Gal $\beta$ 1-4 GlcCer \\
\hline Forssman & GalNAc $\alpha$ 1-3 GalNAc $\beta 1-3$ Gal $\alpha$ 1-4 Gal $\beta$ 1-4 GlcCer \\
\hline Lc3 & GlcNAc $\beta 1-3$ Gal $\beta 1-4$ GlcCer \\
\hline Lc4 & Gal $\beta$ 1-3 GlcNAc $\beta$ 1-3 Gal $\beta$ 1-4 GlcCer \\
\hline $\mathrm{Le}^{a}$ & Gal $\beta$ 1-3 (Fuc $\alpha$ 1-4) GlcNAc $\beta$ 1-3 Gal $\beta$ 1-4 GlcCer \\
\hline $\mathrm{Le}^{b}$ & Fuc $\alpha$ 1-2 Gal $\beta$ 1-3 (Fuc $\alpha$ 1-4) GlcNAc $\beta$ 1-3 Gal $\beta$ 1-4 GlcCer \\
\hline $\mathrm{H}$ & Fuc $\alpha$ 1-2 Gal $\beta$ 1-3 GlcNAc $\beta$ 1-3 Gal $\beta$ 1-4 GlcCer \\
\hline A & GalNAc $\alpha$ 1-3 (Fuc $\alpha$ 1-2) Gal $\beta$ 1-3 GlcNAc $\beta$ 1-3 Gal $\beta$ 1-4 GlcCer \\
\hline B & Gal $\alpha$ 1-3 (Fuc $\alpha$ 1-2) Gal $\beta$ 1-3 GlcNAc $\beta$ 1-3 Gal $\beta$ 1-4 GlcCer \\
\hline nLc4 & Gal $\beta$ 1-4 GlcNAc $\beta$ 1-3 Gal $\beta$ 1-4 GlcCer \\
\hline nLc6, i & $\begin{array}{l}(\mathrm{Gal} \beta \text { 1-4 GlcNAc })_{2} \beta \text { 1-3 Gal } \beta \text { 1-4 GlcCer } \\
\text { Fuc } \alpha 1-2(\mathrm{Gal} \beta 1-4 \text { GlcNAc) } \beta 1-3 \mathrm{Gal} \beta 1-4 \mathrm{GlcCer}\end{array}$ \\
\hline H 2 , & $\begin{array}{l}\text { Fuc } \alpha \text { 1-2 (Gal } \beta 1-4 \mathrm{GlcNAc})_{2} \beta \text { 1-3 Gal } \beta \text { 1-4 GlcCer } \\
\text { Fuc } \alpha 1-2 \mathrm{Gal} \beta 1-4 \mathrm{GlcNAc} \beta 1-3 \mathrm{Gal} \beta 1-4 \mathrm{GlcCer}\end{array}$ \\
\hline $\begin{array}{l}\text { H } 1 \\
A^{a}\end{array}$ & \\
\hline $\begin{array}{l}\mathrm{A}^{a} \\
\mathrm{~B}-\mathrm{I}\end{array}$ & $\begin{array}{l}\text { GalNAc } \alpha 1-3(\text { Fuc } \alpha 1-2) \text { Gal } \beta \text { 1-4 GlcNAc } \beta \text { 1-3 Gal } \beta \text { 1-4 GlcCer } \\
\text { Gal } \alpha 1-3(\text { Fuc } \alpha 1-2) \text { Gal } \beta 1-4 \text { GlcNAc } \beta 1-3 \text { Gal } \beta 1-4 \text { GlcCer }\end{array}$ \\
\hline P 1 & $\mathrm{Gal} \alpha 1-4 \mathrm{Gal} \beta$ 1-4 GlcNAc $\beta$ 1-3 Gal $\beta$ 1-4 GlcCer \\
\hline $\mathrm{Le}^{x}$ & Gal $\beta$ 1-4 (Fuc $\alpha$ 1-3) GlcNAc $\beta$ 1-3 Gal $\beta$ 1-4 GlcCer \\
\hline Gg3 & GalNAc $\beta 1-4$ Gal $\beta 1-4$ GlcCer \\
\hline $\mathrm{Gg} 4$ & Gal $\beta$ 1-3 GalNAc $\beta$ 1-4 Gal $\beta$ 1-4 GlcCer \\
\hline GM3 & NeuAc $\alpha 2-3$ Gal $\beta 1-4$ GlcCer \\
\hline GD3 & NeuAc $\alpha$ 2-8 NeuAc $\alpha$ 2-3 Gal $\beta$ 1-4 GlcCer \\
\hline GM2 & Gal NAc $\beta 1-4$ (NeuAc $\alpha 2-3)$ Gal $\beta$ 1-4 GlcCer \\
\hline GalCer & Gal $\beta$ 1-1 Cer \\
\hline S 3 GalCer & $\mathrm{HSO}_{4}-3 \mathrm{Gal} \beta 1-1 \mathrm{Cer}$ \\
\hline GM4 & NeuAc $\alpha 2-3$ Gal $\beta 1-1$ Cer \\
\hline $\mathrm{SA} \alpha 2 / 3 \mathrm{nLc} 4$ & NeuAc $\alpha 2-3$ Gal $\beta$ 1-4 GlcNAc $\beta$ 1-3 Gal $\beta$ 1-4 GlcCer \\
\hline $\mathrm{SA} \alpha 2 / 6 \mathrm{nLc} 4$ & NeuAc $\alpha$ 2-6 Gal $\beta$ 1-4 GlcNAc $\beta$ 1-3 Gal $\beta$ 1-4 GlcCer \\
\hline SA $\alpha 2 / 3 \mathrm{nLc} 6$ & $\begin{array}{l}\text { NeuAc } \alpha 2-3(\mathrm{Gal} \beta 1-4 \mathrm{GlcNAc})_{2} \beta \text { 1-3 Gal } \beta \text { 1-4 GlcCer } \\
\text { NeuAc } \alpha 2-6(\mathrm{Gal} \beta 1-4 \mathrm{GlcNAc})_{2} \beta 1-3 \mathrm{Gal} \beta 1-4 \mathrm{GlcCer}\end{array}$ \\
\hline SA $\alpha 2 / 6$ nLc6 & \\
\hline $\mathrm{SALe}^{x}$ & $\begin{array}{l}\text { NeuAc } \alpha 2-3 \text { Gal } \beta \text { 1-4 (Fuc } \alpha \text { 1-3) GlcNAc } \beta 1-3 \text { Gal } \beta \text { 1-4 GlcCer } \\
\text { NeuAc } \alpha 2-3 \text { Gal } \beta 1-3(\text { Fuc } \alpha \text { 1-4) GlcNAc } \beta 1-3 \text { Gal } \beta \text { 1-4 GlcCer }\end{array}$ \\
\hline $\begin{array}{l}\text { SALe }{ }^{a} \\
\text { GM1b }\end{array}$ & $\begin{array}{l}\text { NeuAc } \alpha 2-3 \text { Gal } \beta \text { 1-3 (Fuc } \alpha \text { 1-4) GlcNAc } \beta \text { 1-3 Gal } \beta \text { 1-4 GlcCer } \\
\text { NeuAc } \alpha \text { 2-3 Gal } \beta \text { 1-3 GalNAc } \beta \text { 1-4 Gal } \beta \text { 1-4 GlcCer }\end{array}$ \\
\hline GD1c & NeuAc $\alpha$ 2-8 NeuAc $\alpha 2-3$ Gal $\beta$ 1-3 GalNAc $\beta$ 1-4 Gal $\beta$ 1-4 GlcCer \\
\hline GM1 & Gal $\beta$ 1-3 GalNAc $\beta$ 1-4 (NeuAc 2-3) Gal $\beta$ 1-4 GlcCer \\
\hline GD1a & NeuAc $\alpha$ 2-3 Gal $\beta$ 1-3 GalNAc $\beta$ 1-4 (NeuAc 2-3) Gal $\beta$ 1-4 GlcCer \\
\hline GT1a & NeuAc $\alpha$ 2-8 NeuAc $\alpha$ 2-3 Gal $\beta$ 1-3 GalNAc $\beta$ 1-4 (NeuAc 2-3) Gal $\beta$ 1-4 GlcCer \\
\hline GD2 & GalNAc $\beta$ 1-4 (NeuAc $\alpha 2-8$ NeuAc $\alpha 2-3)$ Gal $\beta$ 1-4 GlcCer \\
\hline GD1b & Gal $\beta$ 1-3 GalNAc $\beta$ 1-4 (NeuAc $\alpha$ 2-8 NeuAc $\alpha 2-3$ ) Gal $\beta$ 1-4 GlcCer \\
\hline GT1b & NeuAc $\alpha 2-3$ Gal $\beta$ 1-3 GalNAc $\beta$ 1-4 (NeuAc $\alpha$ 2-8 NeuAc $\alpha 2-3)$ Gal $\beta$ 1-4 GlcCer \\
\hline GQ1b & $\begin{array}{l}\text { NeuAc } \alpha 2-8 \text { NeuAc } \alpha 2-3 \text { Gal } \beta \text { 1-3 GalNAc } \beta \text { 1-4 (NeuAc } \alpha 2-8 \text { NeuAc } \alpha 2-3) \text { Gal } \beta \\
\text { 1-4 GlcCer }\end{array}$ \\
\hline GT3 & NeuAc $\alpha$ 2-8 NeuAc $\alpha$ 2-8 NeuAc $\alpha$ 2-3 Gal $\beta$ 1-4 GlcCer \\
\hline GT2 & GalNAc $\beta$ 1-4 (NeuAc $\alpha$ 2-8 NeuAc $\alpha$ 2-8 NeuAc $\alpha$ 2-3) Gal $\beta$ 1-4 GlcCer \\
\hline GT1c & Gal $\beta$ 1-3 GalNAc $\beta$ 1-4 (NeuAc $\alpha$ 2-8 NeuAc $\alpha$ 2-8 NeuAc $\alpha$ 2-3) Gal $\beta$ 1-4 GlcCer \\
\hline GQ1c & $\begin{array}{l}\text { NeuAc } \alpha 2-3 \text { Gal } \beta 1-3 \text { GalNAc } \beta \text { 1-4 (NeuAc } \alpha 2-8 \text { NeuAc } \alpha 2-8 \text { NeuAc } \alpha 2-3) \text { Gal } \beta \\
1-4 \text { GlcCer }\end{array}$ \\
\hline GP1c & $\begin{array}{l}\text { NeuAc } \alpha \text { 2-8 NeuAc } \alpha \text { 2-3 Gal } \beta \text { 1-3 GalNAc } \beta \text { 1-4 (NeuAc } \alpha 2-8 \text { NeuAc } \alpha \text { 2-8 NeuAc } \\
\alpha \text { 2-3) Gal } \beta \text { 1-4 GicCer }\end{array}$ \\
\hline FucGM1 & Fuc $\alpha$ 1-2 Gal $\beta$ 1-3 GalNAc $\beta$ 1-4 (NeuAc $\alpha$ 2-3) Gal $\beta$ 1-4 GlcCer \\
\hline
\end{tabular}

Cer : セラミド, Glc : グルコース, Gal : ガラクトース, GalNAc : N-アセチルガラクトサミン, GlcNAc : N-ア セチルグルコサミン, Fuc : フコース, NeuAc : N-アセチルノイラミン酸(シアル酸), $\mathrm{HSO}_{4}:$ 硫酸 


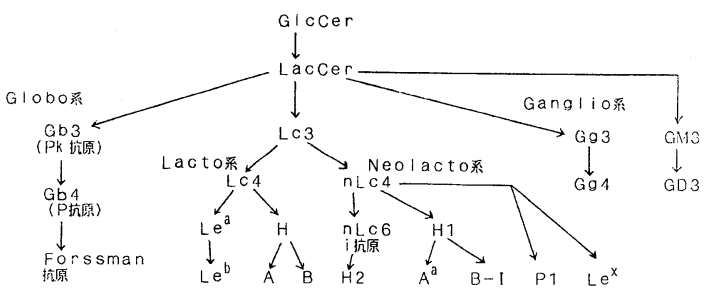

図 1. 赤血球膜の抗原活性糖脂質

などを果している.これら糖脂質の構造決定に当って は, FAB-MS (高速原子衝撃質量分析), NMR ( ${ }^{3} \mathrm{H}$ や $^{13} \mathrm{C}$ の核磁気共鳴測定), メチル化糖分析, エキソ型 とエンド型グリコシダーゼ処理, 構造確定した各種糖脂 質および糖質に対するモノクロナル抗体の使用などに よっている. これら研究法の詳細については, 日本生化 学会編新生化学実験講座 4 , 脂質 III, 糖脂質を参考にし て頂くとして ${ }^{2)}$, 本稿では割愛することにしたい.

筆者は大規模とまでは言えないが，小中規模で私共の 研究室で比較的最近行われた研究のデー夕を基にして, この分野ですでに新しく認められ，また提唱されている 知見などを加えて, 糖脂質の生化学的研究の新展開を総 説できれば幸いだと思っている，もちろん，紙数にも限 りがあるので詳細については参考文献やその他の総説な どに当ってもらいたい. 本稿の内容を理解するためには, 各種糖脂質の名称と構造を知って置くことは重要なこと であるので本稿に掲載される糖脂質はすべて表 1 に纏め ることとする.

\section{2. 血液細胞の成育・分化亡細胞膜糖脂質}

糖脂質の研究は後述する神経系組織についてもっとも 早くから行われたが, わが国の前述した山川らの赤血球 膜糖脂質の研究によって血液細胞についても比較的早く から取り上げられている．今日では，これら血液細胞成 分は未熟な骨䯣幹細胞から多方向性に成育・分化を繰返 して, 成熟した赤血球, 白血球, 血小板からなることは よく知られている.これら血液細胞の種類と, さらに, 各細胞の成育・分化の度合の違いによって細胞膜糖脂質 の組成パターンに特異性や变化が見られることは糖脂質 の生物学的意義や機能の面からも大変注目されるこころ である。

\section{1 赤血球膜の糖脂質}

赤血球膜の糖脂質は全脂質の約 $10 \%$ 前後で, 動物の
膜 (MEMBRANE), Vol. 17 No. 2 (1992)

69

種類によって量と質において特異性を示す. Globo 系 中性糖脂質のうち Globotertraosylceramide (Gb4, グロボシド) や Forssman 糖脂質を主体とするもの, また，シアル酸含有糖脂質（ガングリオシド）の GM3 (ヘマトシド) や GD3 を主体とするものなどさまざま である.この他, 複雑なフコース含有 Lacto 系および Neolacto 系糖脂質（フコリピド）が同定され，これら は $\mathrm{ABH}$, Lewis, P, I などの血液型抗原活性を示すだ けに多くの研究者の注目を惹いていることは言うまでも ない.これら複雑な抗原活性を示す赤血球膜糖脂質の構 造と一連の代謝関連経路を示したものが図 1 である。な お, 赤血球膜糖脂質の詳細については他にもすでに沢山 総説があるのでそれらに譲りたい1 3).

\section{2 白血球の糖脂質}

最近, 白血病細胞の分化, 成熟度, あるいは免疫担当 細胞のそれらと関連して, 白血球のリンパ球や顆粒球の 細胞表面マーカーとしての細胞膜糖脂質のさまざまな発 現が大変関心が持たれるようになり, デー夕も得られて 来ている. 私どもの最近の研究として ${ }^{4)}$, ヒトの骨髄性 およびリンパ性白血病患者の血液より血液成分分離装置 により分離した検体, つまり, 慢性骨髄性白血病, 急性 骨髄性白血病, 急性単球性白血病 (FAB 分類 M $5 a$, 単 芽球; M $5 \mathrm{~b}$, 前单球, 単球), 慢性骨䯣単球性白血病の 各細胞の中性糖脂質と酸性ガングリオシドの分析結果が 表 2 に示されている.

ここから解ることは, 骨髄性白血病細胞の糖脂質は Neolacto 系の中性糖脂質とガングリオシドの他に GM 3 を含んだ．慢性骨髄性白血病細胞は急性のそれより中性 糖脂質が著增するが，ガングリオシド含量には有意な差 がほとんど認められないことが注目された. 慢性と急性 骨髄性白血病細胞の糖脂質組成にも变化が認められ, 急 性では糖脂質の糖鎖の単純なものが相対的に多く, 慢性 になると糖鎖の長いものが相対的に增加する傾向が認め られた。

表 2 にはまた急性リンパ性白血病細胞の非- T, 非-B 細胞と $\mathrm{T}$ 細胞の糖脂質含量と組成が示されているが, その含量は急性骨䯣性白血病細胞のそれに比してさらに 少なく, 中性糖脂質は GlcCer とLacCer がほとんよ゙で, ガングリオシドは GM3 およびGD3で, Neolacto 系の 中性糖脂質もガングリオシドもほとんど認められず，リ ンパ性と骨髄性細胞の顕著な差異が糖脂質組成で見られ ることが注目された。 
表 2. ヒト白血病細胞の中性糖脂質とガングリオシドの含量及び組成

\begin{tabular}{|c|c|c|c|c|c|c|c|c|}
\hline \multirow{2}{*}{\multicolumn{2}{|c|}{$\begin{array}{c}\text { 中性糖脂質含量 } \\
(\mu \mathrm{mol} / \mathrm{g} \text { タンパ質) }\end{array}$}} & \multirow{3}{*}{$\begin{array}{c}\text { GlcCer } \\
5.0\end{array}$} & \multirow{2}{*}{\multicolumn{2}{|c|}{ GalCer }} & \multicolumn{2}{|c|}{ 組成 (mol \%) } & \multirow{3}{*}{$\frac{\mathrm{Gb} 4}{-}$} & \multirow{3}{*}{$\frac{\mathrm{nLc4}}{8.3}$} \\
\hline & & & & & \multirow{2}{*}{$\frac{\text { LacCer }}{84.2}$} & \multirow{2}{*}{$\begin{array}{l}\mathrm{Lc} 3 \\
2.5\end{array}$} & & \\
\hline CML I & 19.7 & & & - & & & & \\
\hline CML II & 16.9 & 5.2 & & 0.6 & 80.8 & 3.1 & - & 10.3 \\
\hline CML III & 21.2 & 5.1 & & 0.5 & 82.0 & 2.3 & - & 10.1 \\
\hline AML (M 1) & 2.9 & 26.8 & & 2.4 & 62.6 & $\operatorname{tr}$ & - & 8.2 \\
\hline AMoL (M 5a) & 3.3 & 12.6 & & 5.1 & 73.2 & 3.1 & $\operatorname{tr}$ & 5.9 \\
\hline AMoL (M 5b) & 2.7 & 55.5 & & 1.7 & 37.0 & $\operatorname{tr}$ & - & 5.8 \\
\hline CMMoL & 2.0 & 27.0 & & 1.4 & 60.4 & $\operatorname{tr}$ & - & 11.2 \\
\hline ALL (L 1) N & 0.8 & 18.2 & & - & 81.8 & - & - & - \\
\hline ALL (L 2) T I & 0.6 & 54.7 & & 7.9 & 37.4 & - & - & - \\
\hline ALL (L 2) T II & 0.4 & 54.1 & & - & 45.9 & - & - & - \\
\hline \multicolumn{2}{|c|}{$\begin{array}{c}\text { ガングリオシド含量 } \\
(\mu \mathrm{mol} / \mathrm{g} \text { タンパク質) }\end{array}$} & GM3 & GD3 & $\begin{array}{l}\mathrm{SA} \alpha 2 / 3 \\
\mathrm{nLc} 4\end{array}$ & $\begin{array}{c}\text { 組成 (mol } \\
\mathrm{SA} \alpha 2 / 6 \\
\mathrm{nLc} 4\end{array}$ & $\begin{array}{l}\text { SA } \alpha 2 / 6 \\
\text { nLc6 }\end{array}$ & $\begin{array}{l}\mathrm{SA} \alpha 2 / 6 \\
\mathrm{nLc} 6\end{array}$ & Others \\
\hline CML I & 1.05 & 20.3 & - & 21.6 & 36.5 & 16.5 & 4.1 & 1.1 \\
\hline CML II & 0.62 & 30.9 & - & 15.3 & 36.0 & 12.4 & 3.5 & 1.8 \\
\hline CML III & 1.41 & 24.2 & - & 16.4 & 37.3 & 15.8 & 4.2 & 2.1 \\
\hline AML (M 1) & 1.01 & 80.2 & - & 8.8 & 6.5 & 3.5 & - & 1.1 \\
\hline AMoL (M 5a) & 1.89 & 54.2 & - & 36.1 & 4.7 & 2.9 & - & 2.1 \\
\hline AMoL (M 5b) & 1.92 & 67.2 & - & 22.0 & 5.8 & 2.6 & $\operatorname{tr}$ & 2.4 \\
\hline CMMoL & 1.36 & 84.8 & - & 7.9 & 4.3 & 1.6 & $\operatorname{tr}$ & 1.4 \\
\hline ALL (L 1) N & 0.51 & 100.0 & - & - & - & - & - & - \\
\hline ALL (L 2) T I & 1.01 & 100.0 & - & - & - & - & - & - \\
\hline ALL (L 2) T II & 0.60 & 45.4 & 52.4 & 1.1 & $\operatorname{tr}$ & - & - & 1.2 \\
\hline
\end{tabular}

CML : 慢性骨髄性白血病, AML : 急性骨䯣性白血病, AMoL : 急性単球性白血病, CMMoL : 慢性単球骨髄性白血 病, ALL ( L 1) N : 急性リンパ性白血病（非 T 非 B 細胞), ALL ( L 2) T : 急性リンパ性白血病（T 細胞）

では, リンパ性細胞の B 細胞についてはどうか。こ のことについて, ごく最近, Wiels らはヒトの B 細胞 系の成育・分化と糖脂質組成と含量に変化が認められる ことを報告している5 ${ }^{5)}$ それによると, Pro-B 細胞では Neolacto 系の中性糖脂質とガングリオシドが認められ るが，そのガングリオシドのシアル酸が NeuAc $\alpha 2 \rightarrow 6$ Gal 結合である.

Pre-B 細胞では Neolacto 系ガングリオシドのシア ル酸が Neu Ac $\alpha 2 \rightarrow 3 \mathrm{Gal}$ 結合で, この他に GM3 の ガングリオシドを含んだ.これら前駆 B 細胞に対して, 活性化した B 細胞では Globo 系の中性糖脂質と GM3 のガングリオシドのみで, Neolacto 系中性糖脂質とガ ングリオシドが消失しているのが注目された。 さらに, B 細胞から形質細胞への分化が進むと, Globo 系中性
糖脂質にはそれ程变化は見られないが, GM3 から GM2 への糖鎖延長がガングリオシドで認められた。なお, $\mathrm{EB}$ ウイルスによる Burkitt リンパ腫細胞では活性化 B 細 胞之同様に Globo 系中性糖脂質として Globotriaosylceramide (Gb3) と Gb4 が認められる他に GM3 のガ ングリオシドも認められた。骨䯣性白血病細胞は ProB 細胞の NeuAc $\alpha 2 \rightarrow 6 \mathrm{Gal}$ 結合を含む Neolacto 系ガ ングリオシドと Pre-B 細胞のNeuAc $\alpha 2 \rightarrow 3 \mathrm{Gal}$ 結合 を含む Neolacto 系ガングリオシドを共有したが, 急性 リンパ性白血病の非- $\mathrm{T}$, 非-B 細胞と $\mathrm{T}$ 細胞は GM3 お よび GD3 のみで, Neolacto 系ガングリオシドをほと んよ゙含まなかった.

この点からも, リンパ性 $\mathrm{T}$ 細胞と $\mathrm{B}$ 細胞が明らかに 区別されうることが示された. 


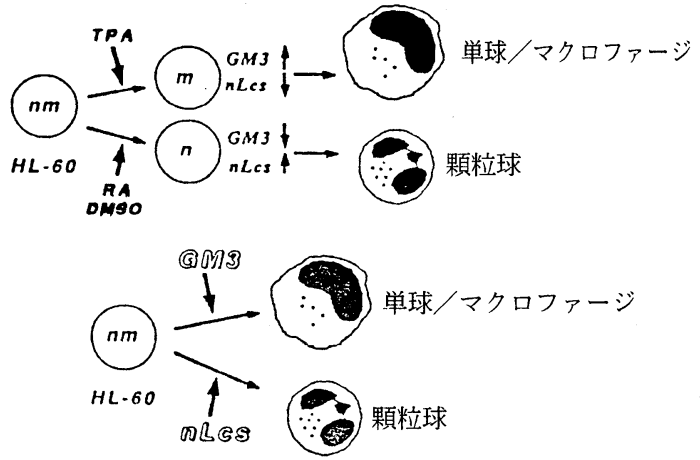

図 2. HL-60 細胞のガングリオシドによる分化誘 導能

$\mathrm{n}$ : 好中球の前駆細胞

$\mathrm{m}$ : マクロファージの前駆細胞

nLcs : Neolacto 系ガングリオシド

表 4. ヒト血小板の糖脂質組成（\%)

\begin{tabular}{c|ccccc}
\hline & GlcCer & LacCer & Gb3 & Gb4 & GM3 \\
\hline 患者 & 3.6 & 32.6 & 12.3 & 27.0 & 24.5 \\
\hline
\end{tabular}

斎藤らはヒト骨髄性白血病細胞, 例えば, HL-60 細 胞系や新鮮な細胞のガングリオシドのパターンが分化段 階のみでなく, 分化の方向性によって変化することを報 告した ${ }^{6.7)}$. Dimethylsulfoxide (DMSO) やレチノイ ン酸 (RA) で誘導される HL-60 細胞の顆粒球への分化 で, NeuAc $\alpha 2 \rightarrow 3 \mathrm{Gal}$ 結合を含む Neolacto 系ガング リオシドの直列に N-acetyllactosamine 繰り返し構造 を有するものが特徴的に増加し, 他方 GM3 は減少し た. 対照的に, HL-60 細胞が TPA (12-o-tetradecanoylphorbol 13-acetate) によって単球/マクロファー ジへ分化するとき, GM3 の増加と Neolacto 系ガング リオシドの減少が同時に観察された. 細胞分化の過程に おけるガングリオシドの増量の生物学的意義を明らかに するために HL-60 細胞の培地に GM3 を添加して見る と, この細胞は単球/マクロファージに分化することが 形態学的にも, 機能の面でも確認された. この細胞増殖 は GM3 の用量依存的に阻害され, $50 \mu \mathrm{M}$ GM3 では完 全に阻害された. 他方, HL-60 細胞の培地に Neolacto 系ガングリオシドを添加すると顆粒球に分化した．以上 のような結果より HL-60 細胞の分化能とガングリオシ ドの分化誘導能を図示したのが図 2 である.
膜 (MEMBRANE), Vol. 17 No. 2 (1992)

71

表 3. モルモット血小板，巨核球の糖脂質組成（\%)

\begin{tabular}{l|cc}
\hline & 血小板 & 巨核球 \\
\hline GlcCer & $15.3 \pm 1.5$ & $34.5 \pm 1.6$ \\
LacCer & $31.5 \pm 3.2$ & $33.3 \pm 0.3$ \\
Gg3 & $53.1 \pm 1.4$ & $32.1 \pm 1.9$ \\
\hline & (平均值 \pm SD) & \\
\hline
\end{tabular}

\section{3 血小板の糖脂質}

最近, Schick らは血小板の糖脂質は巨核球の糖脂質 が決定することをモルモットを用いた実験によって示し ている ${ }^{8)}$. モルモットの巨核球と血小板の糖脂質組成は 表 3 に示されている．筆者ら ${ }^{9)}$ は本態性血小板増多症患 者から血小板を血液成分分離装置で分離し, 洗浄後, 顕 微鏡下でほとんよ゙ $100 \%$ の血小板を確認した。この血小 板より常法により糖脂質を抽出, 分析した結果は表 4 の 通りである. 表 3 と表 4 から判るように血小板の糖脂質 は動物の種差によって明瞭に違っている，モルモットの 血小板の糖脂質は Ganglio 系中性糖脂質で, Gg3 (asialo GM2) が圧倒的に多量を占めたが，モルモットの赤 血球では $91 \%$ 以上がやはり同じ Gg3 で相互にかなり類 似した糖脂質であることが示された．同じことはヒトの 血小板と赤血球の糖脂質においても見られた。 しかしな がら，ヒトの場合は Globo 系中性糖脂質からなること である。

最近, 慢性特発性血小板減少性紫斑病の患者血清中に 糖脂質に対する抗体が見出されている ${ }^{10)}$. とくに, こ れらの抗体は血小板に微量存在するスルファチドと反応 するが，この抗体はカルジオリピンとも交叉反応を示す ので同定には慎重を要する．また，これら抗体には血小 板にやはり微量存在する Neolacto 系ガングリオシドや GD3 とも反応するのでないかと推察されている. 赤血 球にも抗原活性を示す微量の糖脂質が沢山知られている ので血小板の糖脂質についても当然考えられることであ る. 一般には血小板の糖タンパク質抗原についてはよく 知られているが, 血小板減少を惹起する因子として, こ のような糖脂質抗原に対する抗体を考慮することも必要 なことである.

\section{4 血液細胞分化と糖脂質についての考察}

図 3 は前述のヒトの各種血液細胞の糖脂質組成から判 断して, 血液細胞の成熟 - 分化と細胞膜糖脂質の分布之 の関連性を一つに纏めて見たものである. 図 3 に見られ 


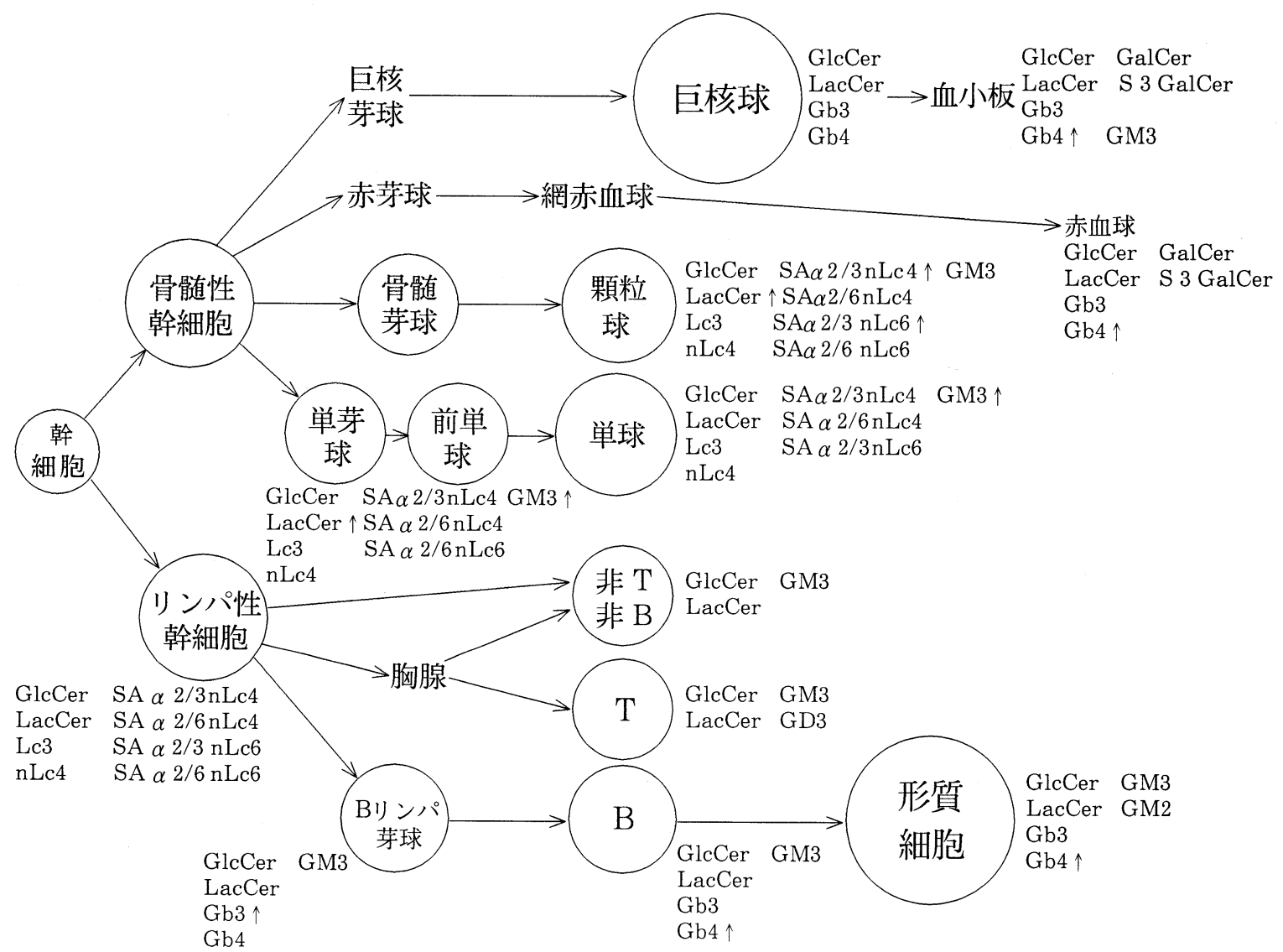

図 3. 血液細胞の成熟・分化之細胞膜糖脂質

るようにWintrobe ら ${ }^{11)}$ はヒトの形態学的には未分化 の状態の骨髄性幹細胞から骨䯣芽球や単芽球が由来し, リンパ性幹細胞からリンパ芽球が由来することを示して いるが，これら細胞の分化は骨髄性およびリンパ性白血 病細胞の糖脂質組成からより一層明らかになる。骨髅性 細胞でも未熟な骨髄芽球ほよ゙ GM3 が多く, Neolacto系 ガングリオシドが少なく, 成熟の顆粒球ほよ゙ GM3 が少 なく, Neolacto 系ガングリオシドが多い，他方，単芽 球, 前単球, 単球では成熟度に関係なく GM3 が $50 \%$ 以 上と比較的多く, Neolacto 系ガングリオシドでは SA $\alpha 2 / 3 n L c 4$ が主体をなしている.

骨髄性細胞でも顆粒球と単球への分化の方向性によっ て糖脂質組成に变化が明らかに認められることは興味深 いことである. リンパ性幹細胞からの $\mathrm{T}$ 細胞, $\mathrm{B}$ 細胞, 非- $\mathrm{T}$, 非-B 細胞への分化によっても糖脂質組成の変化 が明らかに認められる. T 細胞サブ集団抗原として知ら れる CDw60 は GD3， SA $\alpha 2 / 3 \mathrm{nLc} 4, \mathrm{SA} \alpha 2 / 3 \mathrm{nLc} 6$
のようなガングリオシドの糖鎖構造によるものとされて いるが, $\mathrm{T}$ 細胞の糖脂質組成からして果して SA $\alpha 2 / 3 \mathrm{n}$ Lc4, SA $\alpha 2 / 3 \mathrm{nLc} 6$ が存在するかは疑問であるが, GD3 に対するモノクロナル抗体が $\mathrm{T}$ 細胞を增殖させること が知られているので, GD3/CDw60 抗原が $\mathrm{T}$ 細胞膜の 重要な調節分子ではないかと示唆されている. B 細胞の 分化と糖脂質組成の変化はとくに注目される，前駆 B 細 胞と未熟 B 細胞には Neolacto 系の中性糖脂質とガン グリオシドが見られるが, シアル酸の結合が違っている. もっとも両者のガングリオシドは骨䯙性細胞には共存し ている．成熟 B 細胞や活性化 B 細胞になるとよ゙うして Neolacto 系糖脂質が消失して Glolo 系糖脂質になるの かは大変不思議なことであるが興味を惹くところでもあ る. そして, 成熟した B 細胞が必ずしも複雑な糖脂質 を含むものではないことも注目される，もっとも形質細 胞では B 細胞と違って GM2 を発現している. 最近, 扁桃胚中心に $\mathrm{Gb} 3 / \mathrm{CD} 77$ 抗原含有のリンパ球が局在 
していることが分かって，胚中心のリンパ球による抗原

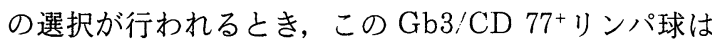
消滅する運命にある．つまりアポプトシス (apoptosis) を受けるのではないか，このことによって高親和性抗体 を産生できない B 細胞が除去される．抗体産生の B 細 胞は $\mathrm{Gb} 3$ を素早く $\mathrm{Gb} 4$ 産生に切り換えて生存するので はないと推察される. B 細胞の分化過程で Neolacto 系 糖脂質から Globo 系糖脂質の切り換えをこのようなア ポプトシスの機序で考えるのも仮説として興味あること である.

このようにして糖脂質を白血球の分化抗原として考え ると，糖脂質が新たに機能的にもきわめて重要なもので あることが認識される。

骨髄性幹細胞からさらに違った方向へ，それぞれ成熟・ 分化した赤血球と血小板は生理学的機能は全く違ってい て，それぞれにきわめて重要な役割を果たしているこよ は言うまでもないが，主要な糖脂質組成は質的に類似性 が見られる，一方抗原活性を有する微量の特異的な糖脂 質には明らかな違いがみられる，両者の成熟度による糖 脂質組成の変化は余り見られないようである.

\section{5 細胞接着分子(セレクチン, Selectin) ファミ リーのリガンド (Ligand) として白血球に見ら れる糖脂質}

細菌感染によって炎症が起ると, 循環中の白血球は血 管壁を通過してその部位に達している.このような場合, 血管内皮細胞は活性化されて 1 種の細胞接着分子である 脊椎動物のレクチン様構造をした糖結合タンパク質 $(E-$ セレクチン) を細胞表面に分泌する. そして，このEセレクチンを介して白血球が血管壁に接着するとき，白 血球表層の糖脂質の糖鎖部分がリガンドの役割を果して いることが明らかになった ${ }^{22}$. ヒト骨䯣性白血病細胞 からこの微量の糖脂質が単離され, 常法により sialyl Lewis $\mathrm{X}\left(\mathrm{SALe}^{x}\right)$ と同定された。なお，この糖脂質は TLC 上で, $E$-セレクチンの決定されたアミノ酸配列を コードする cDNA のプラスミドの移入により放射活性 を帯びた COS 細胞之特異的に結合することも確かめら れた.この $E$-セレクチンは白血球を血管内皮細胞に接 着させることから ELAM-1 (Endothelial-Leukocyte Adhesion Molecule 1) とも呼ばれている. 他方, この $E$-セレクチンのリガンドの役割を果す $S A L \mathrm{e}^{x}$ は白血球 表面マーカーの分化抗原として CD 65 と同じである. なお, $\mathrm{SALe}^{a} も E$-セレクチンのリガンドとなることが
確かめられた ${ }^{3)}$.

つぎに, 活性化血小板が白血球と接着するような場合, 活性化された血小板はその $\alpha$-顆粒から外表層に細胞接 着タンパク質の 1 種である $P$-セレクチンを放出し, こ のP-セレクチンに白血球表層の糖脂質の糖鎖部分がリ ガンドの役割を果していることが分かった ${ }^{14)}$. そして, 血小板と白血球の接着が lacto- $N$-fucopentaose III に よって特異的に阻害されることから, $\mathrm{Le}^{x}$ が白血球表層 でリガンドとして，血小板の $P$-セレクチンと結合する ことが見出されている．このP-セレクチンはPADGEM (Platelet Activation-Dependent Granule-External Membrane) タンパク質, GMP (Granule Membrane Protein)-140 とも呼ばれている.

そして, Le $\mathrm{e}^{x}$ は白血球表面マーカーの分化抗原 CD 15 と見なされている。 また，P-セレクチンは顆粒球や乳 癌細胞に微量存在するスルファチドをリガンドとして結 合するという報告もある ${ }^{15)}$. 以上のような細胞接着分 子のリガンドとして糖脂質が細胞表層に存在することな どが明らかにされて来ると, 糖脂質の生物学的意義はま すます関心が充まるものと思われる.

\section{6 免疫担当細胞之糖脂質}

糖脂質の抗原性の問題については筆者らも以前から携 わって来たが16), これまでも述べられているように一 般に広くこの問題は受け入れられている.ここでは免疫 担当細胞之糖脂質の関連性をこれまで報告されているも のについて少し触れたい。抗 asialo GM1 (Gg4) 抗体 は胎児マウス胸腺や一部の単球と, また, NK 細胞とも 強く反応し，その認識される抗原は分化抗原の性質を もっているのではないかと考えられている．ヒツジ赤血 球に対するマウスの in vitro での抗体産生系で, サプ レッサー T 細胞には Gg4, Gb4, Forssman が存在し, ヘルパー T 細胞にはこれらの糖脂質はなく, GM1が存 在することが知られている。 マクロファージに微量存在 する Fucosyl GM1 はマクロファージの遊走阻止因子 のレセプターの役割をしているのではないかと考えられ

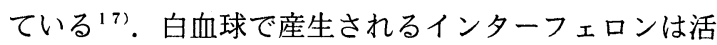
性化 B 細胞に作用して抗体産生細胞への分化を促進す る. また，キラー $\mathrm{T}$ 細胞・ NK 細胞の細胞傷害活性を 増強する．このインターフエロンが作用する細胞表層の レセプターとしての役割をそこに局在するガングリオシ ドが果しているのではないかと考えられて来ている ${ }^{18)}$. 癌細胞から放出される (Shedding) ガングリオシドは 
免疫抑制効果をもつ可能性が示唆されている ${ }^{19)}$.

たとえば, YAC-1 リンパ腫細胞が in vitro で培養さ れるか, in vivo の腹水に注入されるとガングリオシド を合成し, 放出する. そして, この腹水から単離された ガングリオシドはマウスのリンパ球の Con A 誘導によ る細胞増殖応答を阻害することが見られている，癌細胞 はガングリオシドを放出して, 免疫系によって排除され るのを防いでいるのではないかと考えられている.最近, 植物凝集素 PHA で誘導されたヒトのリンパ球の分裂増 殖および Con A で誘導されたサプレッサー T 細胞活性 に及ぼす GM3 とその分解物の効果が検討されている20). GM3 の分解物の Neuraminyllactosylsphingosine (NeuLacSph) と Neuraminyllactosylceramide (Neu LacCer) はFAB-MS で同定された.

この 2 つ分解物は分裂促進因子で誘導されたリンパ 球の分裂増殖の強力な阻害剂であることが分かったが, GM3 とアセチル化した NeuLacSph は効果を示さな かった。

他方, GM3 と NeuLacSph のみは Con A で誘導さ れたサプレッサー T 細胞活性をさらに六進させること ができた。 したがって，GM3 とその分解物のリンパ球 の分裂増殖やサプレッサー T 細胞活性に及ぼす効果 は別々の機序によるものであり, GM3 の $N$-脱アシル 化はリンパ球の分裂増殖の阻害に必須の段階であるここ が示唆された. 免疫担当細胞と糖脂質の問題は前述した $\mathrm{B}$ 細胞の分化と糖脂質代謝とも深い関連があり, ますま す詳細に今後なって行くものと期待される.

\section{3. 神経系組織における糖脂質の役割}

今日では, 哺乳動物のほとんどすべての臓器組織の生 体膜糖脂質について研究がなされて来ているといっても 過言ではない.そして，種々の興味ある知見も得られて 来ているが, 紙数にも限りがあるので筆者の関心のある 神経系組織で特に述べて置かなければならないことにつ にて簡潔に縓めて見ることとする.

\section{1 ミエリン鞘の糖脂質}

哺乳動物の胎生期から出生後にかけての発育急成長期 に脳のミエリン形成は盛んで, その後, 脳の成長に伴っ てミエリン膜も発達する. ミエリン膜は中枢および末梢 神経の軸索の周りをラセン状に多重層のラメラ構造を形 成する.この特殊な膜は絶縁体としての役割を果し, 軸
索に沿った神経ニューロンのインパルスの早い速度の跳 躍伝導が可能なのはそのためである. ミエリン膜の組成 は多くの点で非典型的である.タンパク質含量は少なく, $20 \%$ 程度で, 脂質成分は多量の糖脂質を含み, 主とし てセレブロジ (GalCer) が 24\%, スルファチド (S 3 Gal Cer) が $4 \%$ で，コレステロールが約 $28 \%$ と多く，その 他が種々のリン脂質である. ミエリン膜の脂質組成は絶 縁体の役割を反映している. ミエリン膜のセレブロシド が流動性を示す転移温度が $67^{\circ} \mathrm{C}$ 亡哺乳動物の体温より はるかに高い. したがって，ミエリン膜セレブロシドの 存在は膜構造を固定化し, 同時にイオン透過性を低下さ せる。

哺乳動物の体温では純粋なセレブロシドはゲル状態に あるので, 一般には膜として機能できないので, 高含量 のコレステロールが中等度の流動性を与えて, 膜の流動 性が変らないようにしている. 哺乳動物のミエリンのセ

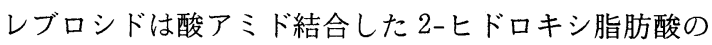
分子種と非ヒドロキシ脂肪酸の分子種が一般に $6 / 4$ の比 率である。

この 2-ヒドロキシル基はアミド基のプロトンやス フィンゴシン塩基や糖のヒドロキシル基と水素結合の ネットワークを形成して, さらに膜の安定化をもたらす ものと考えられている. セレブロシドの 2-ヒドロキシ 脂肪酸の存在は非ヒドロキシ脂肪酸含有セレブロシドが きわめて結晶化し易いのを防ぐ働きをしている．この結 晶化は準安定な水和・脱水のサイクルと関連していて, 水和によるミエリン膜の変化はきわめて破壊的であると 考えられている ${ }^{21)}$. セレブロシドとホスフアチジルコ リンの混合分散は通常余り見られない形態, つまり, 小 さな球状多重層リポゾームと長い多重層細管を示す。こ のリポゾームの屈曲を増大させるセレブロシドはミエリ ン鞘のラセン状に巻いた膜の形成や維持に関与している ものと考えられる ${ }^{22}$. スルファチドはミエリン鞘の 微細構造で鞘細胞の形質膜の内葉同士が融合して主線 (Major dense line) をなすところに局在する塩基性夕 ンパク質と結合していると考えられる. また，外葉同士 は融合せずわずかな間隙 (Intraperiod line) には膜脂 質層に埋もれたプロテオリピドのペプチドの一部が局在 している. ミエリン膜のセレブロシドやスルファチドの 代謝異常による重篤な脱髄性神経疾患を呈するロイコシ ストロフィーはヒトや動物モデルでよく知られていると ころである. また, 種々の病因によって惹起される脱髅 性神経疾患において広くミエリン膜のセレブドロシドや 


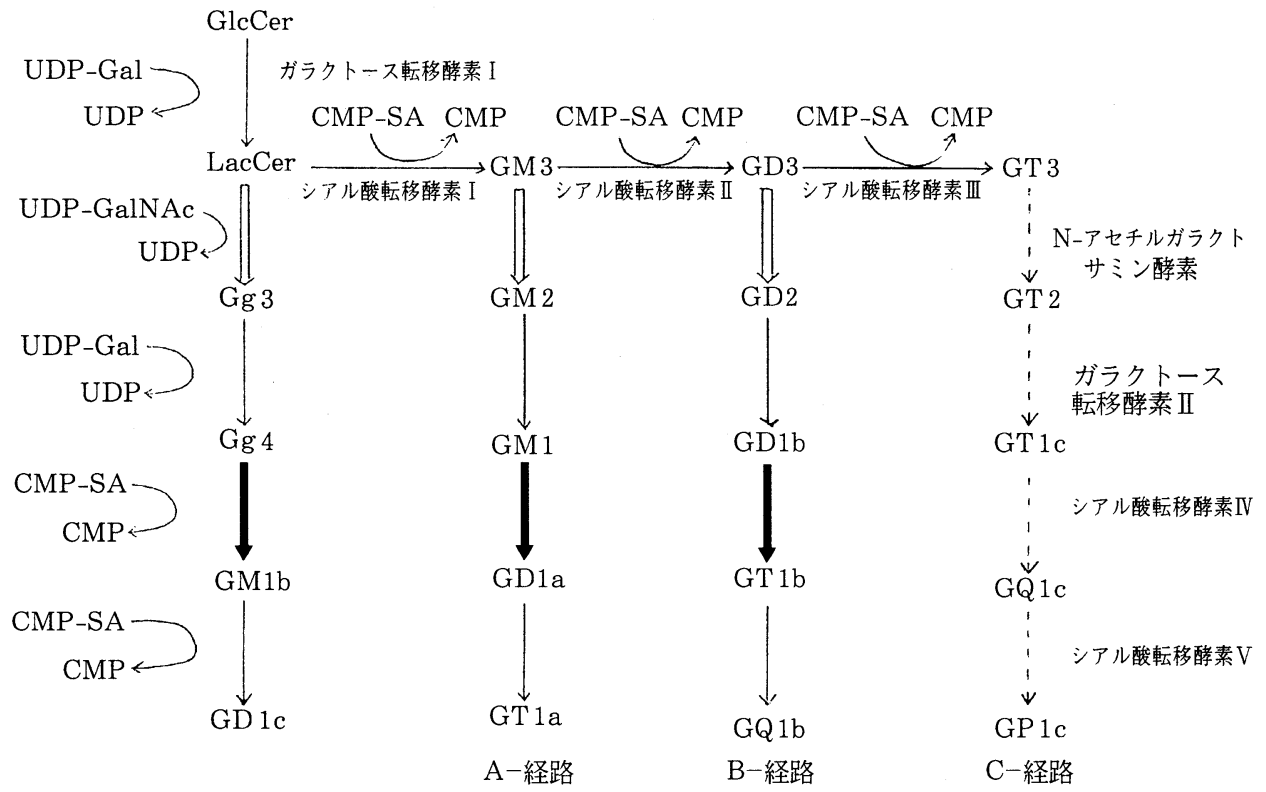

図 4. 脳ガングリオシドの生合成経路の仮説

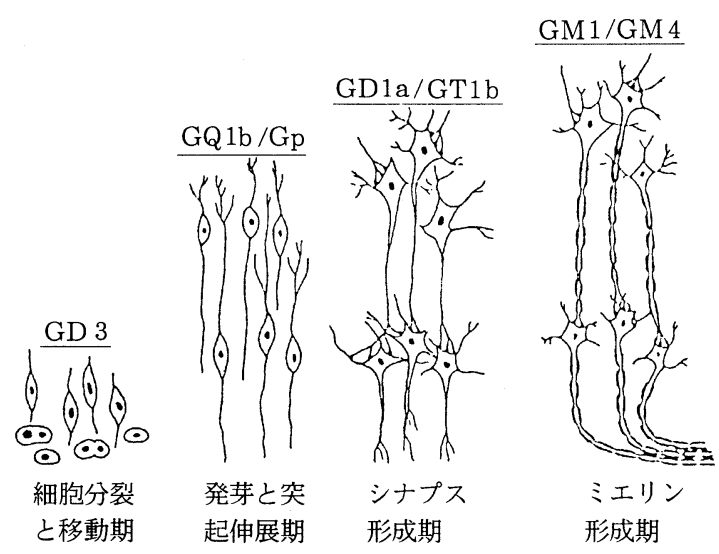

図 5. 神経細胞の発生亡発達段階におけるガング リオシドのマーカーの発現

スルファチドの著減やこれらの構成脂肪酸組成の変動が 見られることも明らかにされている.

これらについては文献について当って欲しい23２42.

\section{2 神経細胞 (ニューロン) のガングリオシド}

今日, とくに, 脳ガングリオシドの生理的機能の役割 について大きな関心が寄せられている ${ }^{25)}$. 永井らは生 理活性ガングリオシド (Bioactive gangliosides) とさ え呼んでいる ${ }^{26)}$.
ニューロンは細胞質を囲んでいくつもの樹状突起を もった細胞体と, そこから長くのびた 1 本の軸索からで きている．神経線維の先端は無髄となって他の神経の細 胞体や樹状突起, または標的細胞に接してシナプスをつ くりネットワークを形成して脳をはじめ身体全体に分布 する.

ガングリオシドは樹状突起や軸索では小胞をなして神 経細胞体とシナプス終末間を順行性や逆行性に比較的早 く輸送されて, 向神経性のフィードバック制御系を維持 しているものと考えられている. ガングリオシドの全生 合成（図 4) はニューロンの核周部のゴルジ一装置で行 われるが, 神経線維終末では生合成も分解も行われない とされている. しかしながら, in vitroやin vivo の実 験結果では部分的な合成や分解が行われうることが示さ れている. ガングリオシドは系統発生的には下等な無脊 椎動物には存在しないが, ウニと脊椎動物に見出されて いる.

脊椎動物の神経系の構築や機能が系統発生的に進歩す るにしたがって, ガングリオシドの濃度も上昇している. 変温動物では脳 $1 \mathrm{~g}$ 当り $100 \sim 800 \mu \mathrm{g}$ のシアル酸含量で あり, 保温動物の鳥類や哺乳類では 400 1500 $\mu \mathrm{g}$ である. 脳の各領域 (たとえば, 前脳, 中脳, 脳幹, 小脳, 春髄) のガングリオシドの濃度は一般的傾向として旧脳領域ほ よ゙減少している．脳ガングリオシドはシアロ・オリゴ糖 
武富 : 血液細胞および神経系組織における糖脂質の多様な役割

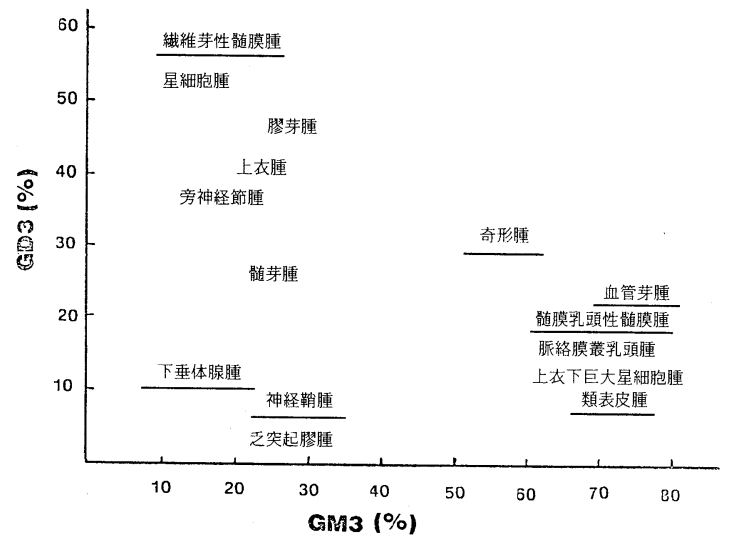

図 6. ヒト脳腫瘍の主要ガングリオシドの組成パ ターン

（下線は脳実質以外の腫瘍）

とセラミド部分の違った約 50 種類が脊椎動物で見出さ れている. 変温動物の脳ガングリオシドは LacCer, Gg 3, $\mathrm{Gg} 4$ の糖コアに多数分子のシアル酸が結合したもの が多く, 保温動物では Gg4 にシアル酸が数個結合した GM1, GD1a, GD1b, GT1b が主要なものである. 個体 発生にあっては, 脳ガングリオシド生成は劇的に変化し, 神経分化の時期之相関しているのが注目される (図 5). ニューロンやその前駆細胞の分裂增殖期には, 比較的単 純な GD3 によって代表され, 複雑なガングリオシドは 見られない. 細胞移動と分化の時期には総ガングリオシ ド生合成が数倍に元進し, GD1a と GT1b が著増し, C 経路のポリシアロガングリオシドは減少する. ミエリン 形成の開始時期には, GM1 と GM4 の増加と蓄積が見 られる. 後期の発達は成熟期にまで続き, オリゴデンド ログリア細胞の増生によって再び GD3 の上昇が見られ る. 老年期には, GD1a が連続的に減少し, 相対的にポ リシアロガングリオシドの割合が高くなり，ニューロン 膜の極性や安定性にも影響を及ぼすものと考えられ $3^{25)}$.

脳ガングリオシドの代謝異常とくに神経細胞のリソ ソームの糖鎖分解酵素の欠損および異常によるガングリ オシド蓄積症としての神経疾患もヒトや動物モデルでよ く知られているので文献に当たって欲しい23.24). この ようなガングリオシドの代謝異常を通してガングリオシ ドの機能的役割をさらに知ることができるのである．私 どもは最近ヒトの脳腫瘍の分類とガングリオシド組成変 化を追求している ${ }^{27)}$. 脳腫瘍は全般的にガングリオシ ドの糖鎖不全が見られ，正常脳と違って GM3 とGD3
の占める比率がきわめて高いことが特徴であり, 腫瘍の 種類によって GM3 と GD3 とその他のガングリオシド の比率が違うことが示されている（図 6). マウスなど の神経芽腫や神経翏腫のガングリオシドについても同様 な変化が認められている. マウスの神経芽腫細胞を培養 して, ガングリオシドの由来するもっとも単純な GlcCer の合成酥素である UDP-グルコース : セラミド・グル コース転移酵素の阻害剤である PDMP (1-Phenyl-2decanoylamino-3-morpholino-1-propanol) を添和 すると細胞の増殖は抑制され, ガングリオシドの生合成 も阻害されることが分かった. 無血清培地での神経芽腫 細胞は神経突起をのばすが, PDMP を加えるとその神 経突起伸展は抑制されるが, GM1 の添加で再び突起伸 展が出現する興味ある現象が見られている ${ }^{28)}$. 種々の 神経芽腫細胞が $\mathrm{Ca}^{2+}$ との関連で, 天然の脳ガングリオ シドのある特定の種類によって神経突起伸展をうながす ことなどは多くすでに報告されている29).ガングリオ シドが神経系でも細胞間認識, 分化および特異的細胞機 能に関与していることはすでに明らかにされて来ている が, これらの一層明確な詳細な機序については今後の神 経科学の各分野からの活発な研究を俟たなければならな いだろう。

\section{文献}

1）山川民夫 : 糖脂質物語, 講談社学術文庫 (1981)

2) 日本生化学会編 : 新生化学実験講座 4, 脂質 III, 糖 脂質, 東京化学同人 (1990)

3) 箱守仙一郎: Scientific American 7, サイエンス （日本版）pp. 71-83 (1986)

4) M. Kyogashima, K. Uemura, T. Taketomi : Jpn J Cancer Res (Gann), 78, 1229-1237 (1987)

5) J. Wiels, M. Mangeney, C. Tetaud, T. Tursz : International Immunol. 3, 1289-1300 (1991)

6) H. Nojiri, F. Takaku, Y. Terui, Y. Miura, M. Saito : Proc Natl Acad Sci, USA, 83, 782-786 (1986)

7) H. Nojiri, S. Kitagawa, N. Nakamura, K. Kirito, Y. Emoto, M. Saito : J Biol Cell, 263, 7443-7446 (1988)

8) P. K. Schick, X. He : J Lipid Res, 31, 16451654 (1990)

9) M. Kyogashima, T. Taketomi : Jpn J Exp Med, 56, 113-118 (1986)

10) H. H. D. M. van Vliet, M. C. Kappers-Klunne, J. W. B. van der Hel, J. Abels: British J Haemat, 67, 103-10 (1987)

11) M. M. Wintrobe, G. R. Lee, D. R. Boggs, T. C. Bithell, J. Foerster, J. W. Athens, J. N. 
Lukens : "Clinical Hematology", 8 th Ed. pp. 35-74, Lea \& Febiger (1981)

12) M. Tiemeyer, S. J. Swiedler, M. Moreland,H. Schweingruber, P. Hirtzer, B. K. Brandley : P roc Natl Acad Sci, USA, 88, 1138-1142 (1991)

13) E. L. Berg, M. K. Robinson, O. Mansson, E. C. Butcher, J. L. Magnani : J Biol Chem, 266, 14869-14872 (1991)

14) E. Larsen, T. Palabrica, S. Sajer, G. E. Gilbert, D. D. Wagner, B. C. Furie, B. Furie : Cell, 63, 467-474 (1990)

15) A. Aruffo, W. Kolanus, G. Walz, P. Fredman, B. Seed : Cell, 67, 35-44 (1991)

16）武富 保, 原 厚 : 代謝 11, 44-56 (1974)

17) D. Y. Liu, K. D. Petschek, H. G. Remold, J. R. David : J Biol Chem, 257, 159-16 (1982)

18) F. Besancon, H. Ankel, S. Basu : Nature, 259, 576-578 (1976)

19) S. Ladish, B. Gillard, C. Wong, L. Ulsh : Cancer Res, 43, 3808-3813 (1983)

20) E. V. Dyatlovitsakaya, A. B. Koroleva, V. S. Suskova, B. V. Rozynov, L. D. Bergelson : Eur
J Biochem, 199, 643-646 (1991)

21) W. Curatolo: Biochemistry, 21, 1761-1764(1982)

22) W. Curatolo, L. J. Neuringer : J Biol Chem, 261, 17177-17182 (1986)

23）武富 保, 脂質代謝異常, 講談社サイエンティフィ ク (1983)

24）玉井洋一，神経生化学下，蛋白質 - 核酸 - 酵素, 29, 1735-1758 (1984)

25) H. Rahmann, H. Wiegandt : Cell to Cell Signals in Plants and Animals (Ed. V. Neuhoff, J. Friend), Springer-Verlag (1991)

26) Y. Nagai, S. Tsuji, J. Nakajima, T. Sasaki : Natural and Biological Activities (Ed. H. Imura, T. Goto, T. Murachi, T. Nakajima) pp. 153-165, University of Tokyo Press (1986)

27）杉山英子, 武富 保, 神経化学 30, 118-119 (1991)

28) K. Uemura, E. Sugiyama, T. Taketomi : J Biochem, 110, 96-102 (1991)

29) G. Wu, R. W. Ledeen, J Neurochem, 56, 95104 (1991)

（受付 1992 年 2 月 7 日） 